\title{
Ethical Leadership Practices and Factors Affecting It in South Addis Ababa District Commercial Bank of Ethiopia
}

\author{
Author(s): Tamene Shomoro Basoro ${ }^{1} \quad$ Belaynesh Tefera (Ph.D.) ${ }^{2}$ \\ 1. Ethiopian Graduate School of Theology, Addis Ababa, Ethiopia \\ 2. Addis Ababa University College of Commerce, Addis Ababa, Ethiopia
}

\begin{abstract}
The study aimed examining ethical leadership practices and factors affecting ethical leadership practices in Commercial Bank of Ethiopia (CBE). In doing so, the research inspected presence of ethical leadership practices. Based on the correlation between ethical leadership and ethical behaviors such as people orientation, fairness, power sharing, ethical guidance, role clarification, integrity and concern for sustainability are indications of ethical leadership practices in CBE. The study again explored effect of ethical dimension or behaviors on leadership practices of the bank. Quantitative research was employed to collect primary data for the study because it is convenient to reduce bias in collecting and analyzing data and mostly the results of quantitative studies are more valid, reliable and can be generalized for the larger population. The finding of the study indicates that there is moderate level of ethical leadership practices in South Addis Ababa District (SAAD) of CBE. Moreover, it was found that ethical leadership practices have positive relationship with ethical behaviors except the fairness dimension which showed weak correlation with the ethical leadership practices of the bank. It was also, discovered that some ethical behaviors such as integrity has high effect on ethical leadership practices. Hence, South Addis Ababa District in particular and Commercial Bank of Ethiopia in general should work to raise the moderate level of ethical leadership to higher level and it is recommended to follow a strategy which strengthen ethical behaviors practices in the organizational leadership practices.
\end{abstract}

Keywords: Ethical leadership, Ethical leadership scale, Ethical leadership behaviors

DOI: $10.7176 / \mathrm{EJBM} / 13-1-01$

Publication date: January $31^{\text {st }} 2021$

\section{Introduction}

Leadership ethics is an area of concern for academicians and practitioners since recent year's scandals in business, government, and sport, non-profit and religious organizations (Brown \& Treviño, 2006, p. 595). According to researches leaders shape ethical environment of an organization whether it is ethical or unethical beginning from top to down having integrity or ethical behavior (Wolmarans, 2014, p. 3). Leaders set the tone of ethical leadership in organizations for the followers to follow their footstep.

Ethical leadership besides supporting organizational success, it also helps organization to be beneficial in these days dynamic competitive business environment since it enables executives to influence followers (CBE Ethiopia, 2012, p. 5). Likewise, ethical leadership has positive effect on behavior of employees and on organizational performance (Hendriks, 2011, p. 5). If leadership of an organization showing ethical behavior it is again logical to assume followers of that organization will have ethical behavior and they adhere to ethical norms of their organization. In the same manner, ethical leadership is vital for organization to be profitable and competitive in business. There are ethical and unethical leadership since the dawn of human civilization; however, its impact is very great in these days organizational setting (Toor \& Ofori, 2009, p. 533). Even though the emphasis of ethical leadership is on outcome of the organization, it takes into account followers affairs of being treated fairly, their leaders to be trustworthy and honest considering them in their decision making for they are assets for the organization they are working. According to Brown and Trevino leaders are expected to be the one who care about people and the broader society, and behave ethically in their personal and professional lives (Alof, 2014, p. 8).

These days in the midst of all challenges it is ethical leadership that brings tranquility and equilibrium setting as a central theme to balance the worst situations happening in business environment (Kar, n.d., p. 111). Furthermore, leaders serve as key source of ethical guidance for employees (Kar, n.d., p. 111) and organization as well. Practices of successful organizations indicates that successful organizations are those organization works to develop their employees by valuing their efforts and works to have committed, enthusiastic, experienced and fairly treated employees (Nancy Langton, n.d., p. 19). Absence of such environment in organizations leads employees to work less hard and responsibly. Recently, the Labor Union and employees of CBE complained and resisted the banks new structure for it lacks justice and fair treatment in assigning employees by reshuffling (Biruk, 2018). Another study also showed that employee's performance measuring system of CBE lacks fairness in assigning employees performing for the bank (Abdurezak Mohammed \& Michael W, 2019, pp. 2-7). Such mistreating hinder employee's belongingness to the company they are working letting the employees less productive, which in turn may lead for high employees turn over in a way affecting the bank unless it is addressed by management and leaders of the bank. CBE requires ethical leaders to manage such scenarios ethically, otherwise it will dent the 
morale of employees. On the other hand, avoiding unfair treating employees, favoring others showing care and treating friendly are ethical leaders character as it is noted by Kanungo, ethical leaders are engaged in acts and behaviors that benefit others, refraining causing any harm to others (Yukl et al., 2013, p. 38). If mangers fails to be ethical in using power of reward, punishing and treating fairly, it creates partiality among employees in a way developing sense of belongingness for some who are favored in the eyes of those respective managers and discomfort for those who are not treated fairly. Unfair treatment of followers with injustice and without having care and concern are manifestation of lack of ethical leadership (Asnake \& Mekonnen, 2019, p. 3) becoming causes for employees turn over from organization they perceive unethical to join other organizations they suppose ethical. On the contrary, fairness, justice and respect for others are among the ethical leadership principles (Northouse, 2013, p. 430) contributing for organization to be successful. Ethical leadership is assumed to possess key ethical dimensions or behaviors like fairness, integrity, ethical guidance, people orientation, power sharing, role clarification and concern for sustainability (Rita Men, 2015, p. 3) which are very crucial factors for organizational leadership practices in ethical manner.

Similarly, the purpose of this study is to explore and find out employee's perception of ethical leadership, to determine the extent to which ethical leadership practices is related with ethical behaviors or ethical dimensions. In addition, it examines ethical leadership practices in relationship with ethical leadership dimensions such as fairness, integrity, ethical guidance, people orientation, power sharing, role clarification and concern for sustainability in CBE South Addis Ababa District and it discusses ethical leadership dimensions that has most effect on ethical leadership of the bank.

\section{Review of Related Literatures Introduction}

Ethical leadership is important for business organization, religious and non-profit organizations to be competitive and viable. Therefore, the need for ethical leadership become center of discussion for practitioners and academicians. In the following section ethical leadership is discussed from both theoretical and empirical perspective.

\section{Theoretical Literature Review Leadership}

Leadership does not have universal definition fitting in all situations but there are almost as many different definitions of leadership as there are persons who have attempted to define the concept (Al \& Ronald, 2013, p. 5). Leadership owns its meaning from the context tried to define it. From behavioral aspect leadership according to Bernard Bass as quoted by Gini Al and M.Green Ronald leadership is the process of guiding and directing the behavior of people in the work environment (Matthew R., 2002, p. 9). Leadership occurs among people involving as leaders and followers. So, it is power-laden, value based and ethically driven relationship between leaders and followers who share a common vision and accomplish real changes that reflect their mutual purpose and goals (Al \& Ronald, 2013, p. 5). It is again a people activity and distinct from administrative paper works or planning activities (Draft, 2008, p. 5) to perform on daily basis. Leadership is a strategy to bring achievement of the vision of the organization. For some it is the ability to influence a group toward the achievement of a vision or set of goals (Robbins \& Dame, 2013, p. 368). For others it is the exercise of influence in a group context (Johnson, 2018, p. 21). Others view leadership as an influence relationship among leaders and followers who intend real changes or outcomes that reflect their shared purpose (Joseph, 1993, p. 102). It is also described as a process where by an individual influence a group of individuals to achieve a common goal (Northouse, 2013, p. 5). Leadership is again seen in contrast with management, where managers are people who do things right and leaders are people who do the right things (Northouse, 2013, p. 13). Having both good leaders and effective managers are important for business and organizations to be competitive.

\section{Ethical Leadership}

Prevailing scandals and fraud in organizations increased significance of ethical leadership. Due to this reason researchers and practitioners are giving due concern for further studying ethical leadership. Even though the need for studying ethical leadership is high, research in this area is few and it is in a very infant stage. Ethical failures are among the most serious problems organizations are facing these days by being impoverished ethical behavior and non-existent ethical leadership (Monahan, 2012, p. 57) which necessitated giving due concern for ethical leadership. Besides, the need for ethical leaders, the way organizations see ethical leadership also matter. For many business organization perceiving ethical leadership as preventing people from doing the wrong thing rather than enabling people to do the right thing (Katja Mihelič, et al., 2010, p. 32) is their concern. To curb such challenges, researchers and practitioners are engaged to look for solution. To do so, they are doing their best to understand what ethical leadership is and its characteristics, its practices and perception in organizations.

De Hoogh and Den Hartog (2009) defined ethical leadership as the process in which a leader influences group 
activities to the organizational goals attainment in a socially responsible way (Ahmad \& Gao, 2017, pp. 12-13). Having seen what ethical leadership is, it is important to look what are the characteristics and what it comprises. Ethical leadership is mainly characterized with two dimensions according to qualitative researches undergone. Ethical leaders must be both strong moral manager and moral person (Ahmad \& Gao, 2017, pp. 12-13). Strong moral person promote ethical conduct and characters at work for their followers. Moral person dimension is known with characters like honest, trustworthy, being approachable, being fair with giving due concern for others, and principle based ethical conduct at work (Brown \& Treviño, 2006, pp. 597-598). In the same manner, moral managers are other dimension in ethical leadership. Strong moral managers are ethically role model, being known with setting and communicating ethical standards and such leaders use rewards to appreciate being comply with standards and to punish follower's failure to be incompliance with standards (Brown \& Treviño, 2006, pp. 597598). In another words, moral leaders walk the talk and talk their walk (Brown \& Mitchell, 2010, p. 584) in their leadership. Both moral person and moral manager are characters that forms ethical dimensions or components of ethical leaders in practices of ethical leadership.

Trevino and his colleagues support ethical leaders being strong moral persons and moral managers. Strong moral managers who are weak moral persons are hypocrites, failing to practice what they preach (Brown \& Treviño, 2006, p. 597) which is contradictory to moral person who possess honesty, trustworthy being giving concern for employee welfare. While strong moral managers who are morally weak person are ethically neutral leaders being silent on ethical issues and suggesting for followers leaders does not care about ethics (Brown \& Mitchell, 2010, pp. 584-585) which is again against strong moral manager's characters.

\section{Ethical Leadership and Ethical Dimensions}

Ethical leadership is the demonstration of normatively appropriate conduct through personal actions and interpersonal relationships, and the promotion of such conduct to followers through two-way communication, reinforcement and decision-making (Brown et al., 2005, p. 120). Ethical dimensions are ethical leader's characters like fairness, power sharing, role clarification, people orientation, integrity, ethical guidance and concern for sustainability. Fairness described as not practicing favoritism, treating other in a way that is right and equal manner enabling to make principled and fair choices (Khan et al., 2017, p. 48). Power Sharing is an opinion enabling employees to have more control their duties, less dependent and having their say in decision making (Khan et al., 2017 , p. 48). Role Clarification is another character which is about clarifying responsibilities and knowing what they will be accountable for and be given every opportunity to use the abilities in achieving objectives to which they have agreed and committed (Armstrong, 2006, p. 324). Again people orientation is among the component of ethical leadership described as real concern for people where ethical leadership reflects genuine care, respect and support for the followers to ensure that their aspirations are fulfilled (Khalid \& Bano, 2015, p. 66). The other important character of ethical leader is integrity that can be seen as being true to oneself showing consistency in words and actions (Palanski \& Yammarino, 2009, p. 406). Moreover, ethical guidance is communicating about ethics, explaining ethical rules, promote and reward ethical conduct (Kalshoven et al., 2010, p. 54) where concern for sustainability is a social responsibility caring about the environment by stimulating and recycling (Kalshoven et al., 2010, p. 54) materials used for different productions and use again and again.

\section{Other Related Leadership Styles with Ethical Leadership}

According to Copeland leaders with leadership styles share similar qualities of authentic, ethical, transformational and value based leadership is more effective than their counter parties that lacks such qualities (Copeland, 2014, p. 131). Considering their similarity and variant leadership dimensions each of them are discussed below.

\section{Authentic Leadership}

Authentic leadership is literally to be true to oneself. As Gardner described authentic leaders are "those who had the ability to acknowledge their thoughts, emotions, needs, wants, preferences, and beliefs and acts with their inner feelings and beliefs (Copeland, 2014, p. 114). Such leaders are aware of themselves striving to persuade and perform what they believe for their subordinate. Avolio described authentic leaders as those who are of how they think and behave and are perceived by others as being aware of their own and others (Celik et al., 2016, p. 190) feelings and moral perspectives as well. Authentic leadership is known with having similar visible futures as ethical leadership; these characteristics are integrity, ethical decision making, being role model for followers and concerned for others but it does not have moral manager aspect that ethical leadership possess (Copeland, 2014, p. 125).

\section{Transformational Leadership}

Transformational leadership is a leadership with vision, self-confidence, and inner strength to argue successfully for what is good or right (Armstrong, 2006, p. 22). As described by Bass transformational leadership has four components, these are idealized influence, inspirational motivation, intellectual stimulation and individualized 
consideration (Bass \& Riggio, 2006, pp. 6-7). Such influential components transformational leadership has other side which is pseudo transformational leadership. It lacks transformational leadership qualities such as authentic, moral and ethical dimension of transformational leadership (Copeland, 2014, p. 122). It is less effective than transformational leadership.

\section{Value Based Leadership}

Value is part of the vision and it is the proper means for attaining visions (Locke, 2009, p. 375) of the organizations. When it comes to value based leadership, it is a value-driven influence of followers to achieve an organizational vision. Value based leadership is a kind of leadership where transparency promotes trust through leadership action, traits (mutual understanding by shared beliefs and values) and experiences (Yardley et al., 2012, p. 27). Value based leadership emerged and concern is given to it due to ethical failures and crisis prevalent in global organization since it has behavior that is rooted in ethical and moral foundation (Copeland, 2014, p. 106). So as to curb the challenges that various global organizations are facing. Value-based leadership is a leadership philosophy focusing on who the person is and how he behaves rather than the positional power he holds (Taylor, 2010, p. 5). The positional power he has is with worthy responsibility for his personal, organizational and for the society in general. According to Jansen Kraemer value-based leadership has four principles which is distinct and distinguishing it from other leadership styles. These principles are the self-reflection, the balance, the true selfconfidence and the genuine humility (Vima, 2018, p. 54). For personal, organizational and societal benefit leading with value by evaluating its successfulness is important even though it is not a cure for all the challenges leaders are encountering

\section{Empirical literatures Review}

\section{Dimensions or Ethical Leadership Behaviors and Ethical Leadership Practices}

Several Literatures support the correlation between behaviors and ethical leadership. Reyhane Khodarahmi and Taghi Aghahoseini in their research of assessing the relationship between ethical leadership and empowerment of employees in the tax affairs of Isfahan City confirmed that multidimensional scale (fairness, ethical guidance, people orientation, power sharing, role clarification, integrity and concern for sustainability) of Kalshoven is positively associated with transformational and transactional leadership (Khodarahmi \& Aghahoseini, 2014, p. 283), and Karianne Kalshoven, Deanne N. Den Hartog and Annebel H. B. De Hoogh exploring ethical leader behavior and big five factors of personality, they found that ethical leadership behaviors like fairness, role clarification, people orientation and integrity are parallel with ethical leadership (Kalshoven et al., 2011, pp. 349363).

In another research done to develop ethical leadership measure for public service in Sri Lanka by R. Lalitha $\mathrm{S}$. Fernando indicates that there is direct relationship and effect between ethical leadership and ethical behaviors such as; fairness, people orientation, power sharing, ethical guidance, role clarification, integrity but concern for sustainability failed to show relation with ethical leadership (S. Fernando, 2018, pp. 106-119). This findings affirm previous ethical leadership behaviors contributing to ethical leadership practicability in organizations. Empirical research on determinants of ethical leadership is less convincing with mixed view on ethical behaviors due to limitation of generalization in individual and group level (Brown et al., 2005, p. 119). Where few empirical review conducted by Trevino indicates employee's perception of ethical leadership is positively related with concern for people, fair treatment and demonstrating integrity (Katja Mihelič, et al., 2010, p. 34) in organizations. Kalshoven and her colleagues found that ethical leadership is positively related with power sharing, fairness, people orientation, concern for sustainability, ethical guidance, role clarification \& integrity (Kalshoven et al., 2010, p. 57) indicating that existence of remarkable relationship between ethical dimensions and ethical leadership.

Study which was conducted in public sector university of Pakistan showed that there is a positive relation between ethical leadership practice and organizational citizenship behavior which in turn positively correlated with people orientation, fairness, power sharing, and concern for sustainability, ethical guidance, role clarification and integrity (Khan et al., 2017, p. 45). An exploratory research conducted in Malaysia revealed that people orientation, fairness, power sharing, and concern for sustainability, ethical guidance, role clarification and integrity are ethical behaviors positively related with ethical leadership as per the perception of respondents, where integrity is highly related and fairness is less positively related than others (Rahim \& Ahmad-Zaluki, 2018, p. 54). According to an investigation done by Islamic Tertiary Educational institution academic staff, perception of ethical leadership practice of the school is positively related with role clarification, integrity and concern for sustainability (Johdi Salleh \& Arryani Tiyunin, 2014, p. 43) while there is need for further conducting studies determining perception of ethical leadership and ethical behaviors influencing ethical leadership practices. The German version of ethical leadership at work questionnaires affirm existence of positive correlation and direct effect between ethical leadership behaviors such as fairness, people orientation, power sharing, concern for sustainability, ethical guidance, role clarification and integrity analyzing it with ethical leadership (Steinmann et al., 2016, pp. 1-17). In the same way, in research from ethical dimension power sharing do not show correlation in study of ethical leader 
behavior and leader effectiveness (Kalshoven \& Hartog, 2009, p. 102). Research conducted in ethical leadership towards organizational commitment in schools showed that ethical dimensions like fairness, integrity, power sharing, role clarification and concern for sustainability does not show significant relation and effect on ethical leadership (Ismail \& Yaakob, 2014, pp. 5-6). According to different studies in ethical leadership, some dimensions of ethical leadership are correlated with ethical practice of the organizations while other did not in studies conducted in different countries and in different organizations.

\section{Conceptual Framework}

The study has ethical dimensions such as fairness, integrity, ethical guidance, people orientation, power sharing, role clarification and concern for sustainability are independent variables, whereas ethical leadership is dependent variable.
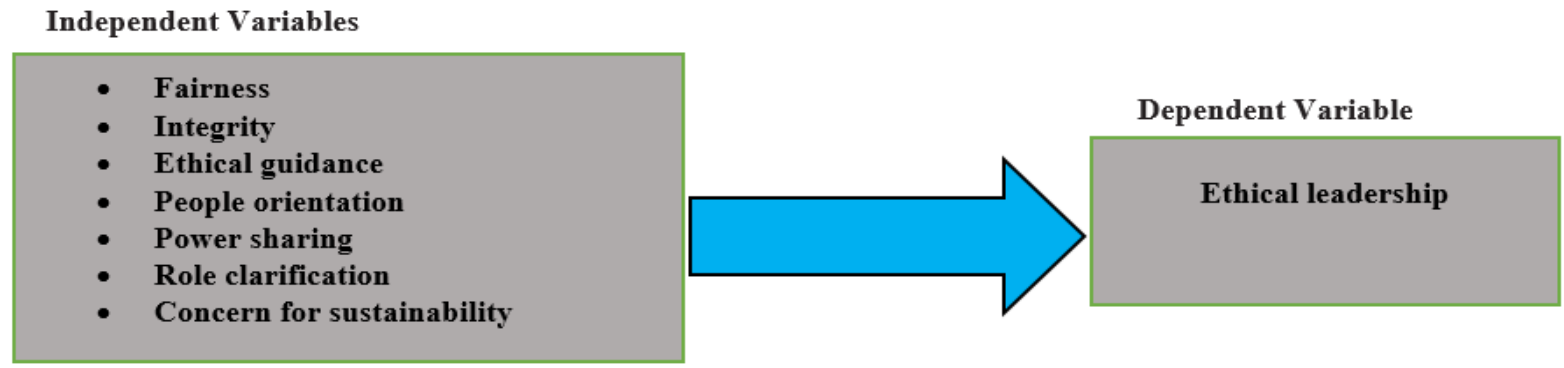

Diagram 1. Concepts are taken from ethical leadership at work questionnaire (ELW) (Kalshoven et al., 2010).

\section{Methodology}

\section{Population and Sampling}

The study used proportional stratified random sampling technique to collect data from thirty five branches randomly selected from one hundred five branches in South Addis Districts of CBE to have fair representative of all branches. Ten employees from each selected branches were communicated. The study determined the sample size using sample size determination formula.

\section{Instrumentation}

Ethical leadership scale and ethical leadership at work questionnaires were used to measure perception of CBE employee's ethical leadership practices and to determine how ethical leadership practices was related with ethical leadership behavior and its impact on ethical leadership practices. Ethical leadership scale comprises 10 items whereas ethical leadership at work questionnaires scale has 38 items and both scales were used to assess ethical leadership perception and factors affecting ethical leadership as well.

\section{Data Analysis}

The study analyzed data using different statistical methods such as descriptive (frequencies, percentages, means and standard deviation), statistical correlation and regression.

\section{Reliability Analysis}

Though the study uses standardized scales. Internal consistency analysis was carried out through Cronbach alpha reliability tests in order to re-affirm the liability of the questionnaires.

\section{Table 3.1 Reliability Analysis of the Items}

\begin{tabular}{|l|l|l|l|}
\hline No. & Descriptions & Cronbach'S Alpha & Number of Items \\
\hline 1 & Power Orientation & 7 & 0.854 \\
\hline 2 & Fairness & 6 & 0.876 \\
\hline 3 & Power Sharing & 6 & 0.865 \\
\hline 4 & Concern for Sustainability & 3 & 0.870 \\
\hline 5 & Ethical Guidance & 7 & 0.840 \\
\hline 6 & Role clarification & 5 & 0.851 \\
\hline 7 & Integrity & 4 & 0.831 \\
\hline 8 & Ethical Leadership Scale & 10 & 0.847 \\
\hline
\end{tabular}

\section{Source: Survey 2020}

The Cronbach's alpha result presented above measure the internal consistency or reliability of the instruments or scales used in the study. The result of Cronbach's alpha satisfy and above the minimum required threshold in social science researches suggestion of Cronbach's alpha value of .70 to .95 is an acceptable range of interval (Tavakol \& Dennick, 2011, p. 54) indicating that Cronbach's alpha result is consistent and reliable. 


\section{Findings and Discussion}

The researchers distributed 370 questionnaires to collect the required data but only 322 questionnaires out of distributed questionnaires were returned which is with $87 \%$ return rate.

\section{Descriptive Statistics of the Variables}

In this study, descriptive statistics such as mean and standard deviation are used to examine the perception of ethical leadership in CBE employees of SAAD. The mean score and standard deviation of both independent variables and dependent variables are listed and described below in the following table.

\section{Table 4.1 Descriptive Statistics}

\begin{tabular}{|c|c|c|c|c|c|}
\hline Variables & $\mathrm{N}$ & Minimum & Maximum & Mean & Std. Deviation \\
\hline \multicolumn{6}{|l|}{ Independent Variables } \\
\hline \begin{tabular}{|l|} 
Power Orientation \\
\end{tabular} & 322 & 1 & 5 & 3.23 & .753 \\
\hline Fairness & 322 & 1 & 5 & 3.02 & .825 \\
\hline Power Sharing & 322 & 1 & 5 & 3.15 & .666 \\
\hline Concern for Sustainability & 322 & 1 & 5 & 3.28 & .830 \\
\hline Ethical Guidance & 322 & 1 & 5 & 3.39 & .738 \\
\hline Role Clarification & 322 & 1 & 5 & 3.47 & .791 \\
\hline Integrity & 322 & 1 & 5 & 3.34 & .837 \\
\hline \multicolumn{6}{|l|}{ Dependent Variable } \\
\hline \begin{tabular}{|l|} 
Ethical Leadership Scale \\
\end{tabular} & 322 & 1 & 5 & 3.33 & .704 \\
\hline
\end{tabular}

\section{Survey 2020}

Ethical leadership at work questionnaires which was developed by Kalshoven (2011) consists of 38 items divided into seven ethical dimensions such as fairness (6 items), power sharing (6 items), role clarification (5 items), people orientation ( 7 items), ethical guidance ( 7 items), integrity ( 4 items) and concern for sustainability (4 items). The overall scale consists of 38-190 items and the higher the mean score is indication of the higher ethical leadership (Rahim \& Ahmad-Zaluki, 2018, p. 58), whereas mean score ranging from 38-88 indicates low ethical leadership, mean score beginning from 89 to 139 is indication of moderate ethical leadership and mean score above 140 shows higher ethical leadership prevalence (Ali Award \& Ali Khalif, 2018, p. 44). Similarly, ethical leadership scale which was developed by Dr. Michael Brown is mostly used to assess and examine ethical leadership in organization consists 10 items. According to the developer, 3 is the mid-point to discern existence of ethical leadership, mean score above 3 represent ethical leadership where below 3 is indication of weak or negative ethical leadership prevalence (Fowler, 2014, p. 237) and Craig.E Johnson described ELS scoring by adding the 10 items, the higher the score is the better ethical leadership indications of leaders (Johnson, 2018, p. 28). Hence, the analysis implies presence of that ethical leadership practices in SAAD Commercial Bank of Ethiopia in moderate ethical leadership level.

\section{Correlation}

So as to get the strength of relationship between dependent variable (ELS) and independent variable (ELW) or ethical behaviors, a Pearson correlation analysis was performed. 
Table 4.2: Correlation Analysis

\begin{tabular}{|c|c|c|c|c|c|c|c|c|c|}
\hline & TPO & TF & TPS & TCFS & TEG & TRC & TI & TELS \\
\hline \multirow{2}{*}{$\begin{array}{l}\text { Power } \\
\text { Orientation (PO) }\end{array}$} & Pearson Correlation & & $.293^{* *}$ & $.643^{* *}$ & $.597^{* *}$ & $.574^{* *}$ & $.524^{* *}$ & $.639^{* *}$ & $.642^{* *}$ \\
\hline & Sig. (2-tailed) & & .000 & .000 & .000 & .000 & .000 & .000 & .000 \\
\hline \multirow[t]{2}{*}{ Fairness (F) } & Pearson Correlation & $.293^{* *}$ & & $266^{* *}$ & $.323^{* *}$ & $.277^{* *}$ & $.214^{* *}$ & .084 & $.273^{* *}$ \\
\hline & Sig. (2-tailed) & .000 & & .000 & .000 & .000 & .000 & .130 & .000 \\
\hline \multirow{2}{*}{$\begin{array}{l}\text { Power Sharing } \\
\text { (PS) }\end{array}$} & Pearson Correlation & $.643^{* *}$ & $.266^{* *}$ & & $.550^{* *}$ & $.539^{* *}$ & $.473^{* *}$ & $.562^{* *}$ & $.573^{* *}$ \\
\hline & Sig. (2-tailed) & .000 & .000 & & .000 & .000 & .000 & .000 & .000 \\
\hline \multirow{2}{*}{$\begin{array}{l}\text { Concern for } \\
\text { Sustainability } \\
\text { (CFS) }\end{array}$} & Pearson Correlation & $.597^{* *}$ & $.323^{* *}$ & $.550^{* *}$ & & $.538^{* *}$ & $.489^{* *}$ & $.551^{* *}$ & $.577^{* *}$ \\
\hline & Sig. (2-tailed) & .000 & .000 & .000 & & .000 & .000 & .000 & .000 \\
\hline \multirow{2}{*}{$\begin{array}{l}\text { Ethical Guidance } \\
\text { (EG) }\end{array}$} & Pearson Correlation & $.574^{* *}$ & .277 & $.539^{* *}$ & $.538^{* *}$ & & $.637^{* *}$ & $.613^{* *}$ & $.619^{* *}$ \\
\hline & Sig. (2-tailed) & .000 & .000 & .000 & .000 & & .000 & .000 & .000 \\
\hline \multirow{2}{*}{$\begin{array}{l}\text { Role } \\
\text { Clarification } \\
(\mathrm{RC})\end{array}$} & Pearson Correlation & $.524^{* *}$ & $.214^{* *}$ & $.473^{* *}$ & $.489^{* *}$ & $.637^{* *}$ & & $.582^{* *}$ & $.551^{* *}$ \\
\hline & Sig. (2-tailed) & .000 & .000 & .000 & .000 & .000 & & .000 & .000 \\
\hline \multirow[t]{2}{*}{ Integrity (I) } & Pearson Correlation & $.639^{* *}$ & .084 & $.562^{* *}$ & $.551^{* *}$ & $.613^{* *}$ & $.582^{* *}$ & & $.702^{* *}$ \\
\hline & Sig. (2-tailed) & .000 & .130 & .000 & .000 & .000 & .000 & & .000 \\
\hline \multirow{2}{*}{$\begin{array}{l}\text { Ethical } \\
\text { Leadership Scale } \\
(\text { ELS) }\end{array}$} & Pearson Correlation & $.642^{* *}$ & $.273^{* *}$ & $.573^{* *}$ & $.577^{* *}$ & $.619^{* *}$ & $.551^{* *}$ & $.702^{* *}$ & \\
\hline & Sig. (2-tailed) & .000 & .000 & .000 & .000 & .000 & .000 & .000 & \\
\hline
\end{tabular}

** Correlation is significant at the 0.01 level (2-tailed).

The sign of correlation coefficient is used to determine and indicate whether the correlation is positive or negative whereas the magnitude of the correlation coefficient determines the strength of the correlation. To describe the strength of the correlation, the Evans (1996) suggestion is used. Evans (1996) suggested that, for the absolute value $\mathrm{r}$ used in correlation from $0.00-0.19$ is very week, $0.20-0.39$ is weak, $0.40-0.59$ is moderate, $0.60-$ 0.79 is strong and $0.80-1.00$ is very strong (Melesse, 2017, p. 55). From this it can be understood that the relationships, the inter correlations among the variables is in inconformity with the assumed or hypothesized direction.

Significant correlation exists between ethical leadership and the ethical behavior or dimensions. All the dimensions and ethical leadership indictor is positively varying being correlated. The positive relationship between F and ELS is $(r=0.084, p<0.01)$, PS and ELS is $(r=0.573, p<0.01)$, CFS and ELS is $(r=0.577, p<0.01)$, RC and ELS is $(r=0.551, p<0.01)$, PO and ELS is $(r=0.642, p<0.01)$, EG and ELS is $(r=0.619, p<0.01)$ and $\mathrm{I}$ and $E L S$ is $(R=0.702$, $\mathrm{r}<0.01$ ). Concerning the strength of relationships: $\mathrm{F}$ is weak in relation to ELS, PS, CFS, and RC are moderately related with ELS and PO, and EG and I are strongly related with ELS.

The relationship between dependent and independent variables in this study which shows positive correlation with varying figures and in weak, moderate and strong strength of relationship is not without support from literatures. Except concern for sustainability, the other six dimensions are positively overlapping with ELS (Day, 2014, p. 534) and in another study ELW is correlated positively in significant manner with ELS (Kalshoven et al., 2010 , p. 63). In the same manner, validation of a German version of ethical leadership at work questionnaire revealed that a higher correlation is displayed between ELW-D and ELS-D than any other destructive leader behavior (Steinmann et al., 2016, pp. 1-17). Hence, relaying on previous works and on data analysis of the correlation on ethical leadership, it can be understood that the independent variables are positively related with dependent variable ethical leadership.

\section{Regression Analysis}

So as to know by how much the independent variables explain the dependent variable, regression analysis was performed. The regression was undertaken between sub-scales or dimensions of independent variables (people orientation, fairness, power sharing, ethical guidance, role clarification, integrity and concern for sustainability) and dependent variable ethical leadership scale. The result of regression analysis is presented below in three tables.

$R, R^{2}$, adjusted $R^{2}$ and the standard error of the estimate, which is used to determine how well a regression model fits the data. The multiple correlation coefficient, $\mathrm{R}$ is a measure of the quality of the prediction of the independent variable and the coefficient of determination or $\mathrm{R}^{2}$ is the proportion of variance in the dependent variable that can be explained by the independent variables. The F-ratio in the ANOVA table tests whether the overall regression model is a best fit for the data and the multiple regression model depicts results of tests for the significance of each of the independent variable. 
Table 4.3: Model Summary

\begin{tabular}{|l|l|l|l|l|}
\hline Model & R & R Square & Adjusted R Square & Std. Error of the Estimate \\
\hline 1 & $.782^{\mathrm{a}}$ & .611 & .602 & 4.444 \\
\hline
\end{tabular}

a. Predictors: (Constant), TI, TF, TPS, TRC, TCFS, TEG, TPO

From the table above, the value of $\mathrm{R}=0.782$, indicates a positive prediction of independent variables on dependent variable ELS, the value of $\mathrm{R}^{2}=0.611$ indicates the independent variable explain $61.1 \%$ variability on dependent variable.

Table 4.4: ANOVA $^{\mathrm{a}}$

\begin{tabular}{|l|l|l|l|l|l|l|}
\hline \multicolumn{2}{|l|}{ Model } & Sum of Squares & df & Mean Square & F & Sig. \\
\hline \multirow{3}{*}{1} & Regression & 9716.004 & 7 & 1388.001 & 70.289 & $.000^{\mathrm{b}}$ \\
\cline { 2 - 8 } & Residual & 6180.844 & 313 & 19.747 & & \\
\cline { 2 - 7 } & Total & 15896.847 & 320 & & & \\
\hline
\end{tabular}

a. Dependent Variable: TELS

b. Predictors: (Constant), TI, TF, TPS, TRC, TCFS, TEG, TPO

The ANOVA table tells that the independent variable significantly predicts the dependent variable, $\mathrm{F}(7,313)$ $=70.289, \mathrm{P}<0.05$ indicting that the regression model is a best fit of the data.

Table 4.5: Coefficients ${ }^{\mathrm{a}}$

\begin{tabular}{|c|c|c|c|c|c|c|}
\hline \multirow{2}{*}{\multicolumn{2}{|c|}{ Model }} & \multicolumn{2}{|c|}{ Unstandardized Coefficients } & \multirow{2}{*}{$\begin{array}{l}\text { Standardized Coefficients } \\
\text { Beta }\end{array}$} & \multirow[b]{2}{*}{$\mathrm{t}$} & \multirow[b]{2}{*}{ Sig. } \\
\hline & & $\mathrm{B}$ & Std. Error & & & \\
\hline \multirow[t]{8}{*}{1} & (Constant) & 3.899 & 1.491 & & 2.616 & .009 \\
\hline & Power Orientation (PO) & .206 & .073 & .154 & 2.832 & .005 \\
\hline & Fairness $(\mathrm{F})$ & .128 & .056 & .090 & 2.292 & .023 \\
\hline & Power Sharing (PS) & .152 & .088 & .085 & 1.725 & .086 \\
\hline & Concern for Sustainability (CFS) & .288 & .137 & .102 & 2.099 & .037 \\
\hline & Ethical Guidance (EG) & .191 & .072 & .140 & 2.671 & .008 \\
\hline & Role Clarification (RC) & .088 & .087 & .050 & 1.011 & .313 \\
\hline & Integrity (I) & .796 & .114 & .378 & 6.994 & .000 \\
\hline
\end{tabular}

a. Dependent Variable: ELS

From multiple regression model to predict the ELS from the dimensions of independent variables (PO, F, PS, CFS, $\mathrm{EG}, \mathrm{RC}$ and I) are being significant at $\mathrm{P}<0.05$. Therefore, it can be concluded that among the dimensions $\mathrm{PO}, \mathrm{F}$, CFS, EG and I predict the dependent variable significantly. PS and RC do not predict the dependent variable significantly since their $\mathrm{p}$ value 0.86 and 0.313 which are greater than 0.05 . Comparing the independent variables significantly predicting the dependent variable, I with standardized beta coefficient 0.378 predicts more than the other dimensions with standardized beta coefficient with $0.005,0.023,0.037$ and 0.008 . This result implies that the leadership practices of the bank need to have different initiatives and mechanisms to work on ethical leadership.

The result of the regression analysis is in agreement with previous studies conducted such as, ethical leadership at work questionnaire (ELW): development and validation of a multidimensional measure (Kalshoven et al., 2010, pp. 63-64) by Karinne Kalshoven,Deanne N. Den Hartog, and Annebel H.B. De Hoogh, and validation of German version of the ethical leadership questionnaires (Steinmann et al., 2016, pp. 10-11) by Barbara Steinmann, Annika Nubold and Gunter W. Maier. Depending on the analysis working on dimensions of ethical leadership such as integrity, fairness, ethical guidance and concern for sustainability have impact on ethical leadership. For CBE in general and for SAAD in particular practicing ethical leadership taking the mentioned dimensions in consideration can result in boosting the ethical leadership practices of the bank for a much better level

Inferential statistics implies that ethical behaviors people orientation, fairness, concern for people, ethical guidance and integrity have positively contributing impact on ethical leadership practices of the bank. From ethical dimensions, role clarification and power sharing have weak or no impact on ethical leadership practices of the bank. Integrity is highly significant and influencing factor of ethical leadership practices in CBE from all ethical behaviors, followed by people orientation, ethical guidance, fairness and concern for sustainability respectively.

\section{Conclusion and Recommendations \\ Conclusion}

This research mainly aims to explore employee's perception of ethical leadership practices in SAAD and to what extent ethical leadership dimensions or behaviors are related and influencing ethical leadership practices of the bank. Addressing the main objective the study focuses on investigating and discussing employee's perception of ethical leadership in relation with dimensions of ethical leadership. Besides, the research was aiming at examining the relationship between ethical leadership practices and ethical behaviors or dimensions and explaining and analyzing factors or effect of ethical behaviors contributing to ethical leadership practices in CBE South Addis 
Ababa District. To come across with finding, quantitative method was used in the study by using descriptive, exploratory and inferential analysis and interpretations of the data are employed. Primarily, based on the finding the research reveals presence of ethical leadership practices in SAAD, Commercial Bank of Ethiopia where the extent of its practice is at moderate level.

Depending on the finding among the ethical dimensions fairness showed weak correlation with the ethical leadership practices implying that the presence of fairness in ethical leadership practice is weak. This indicates that employees in SAAD Commercial Bank of Ethiopia are not being treated fairly in relation with ethical leadership practice where the significance of fairness is high for ethical leadership practices in the bank.

From the ethical dimensions integrity has significant influence on ethical leadership practices of the bank that means integrity matters most for the bank on real practice of ethical leadership in the bank; however, role clarification and ethical guidance have weak influencing effect on ethical leadership that means there is gap clarifying role and applying ethical guidance in SAAD, Commercial Bank of Ethiopia.

Even though the study indicates presence of ethical leadership practice moderately, depending on level of practice of ethical leadership especially some ethical behaviors are more exercised than other, among these behaviors role clarification and ethical guidance are mostly practicable dimensions followed by integrity, power sharing, people orientation and concern for sustainability.

Some ethical behaviors showed very significant impacting on ethical leadership practices, still there are factors do not showing significance and impact or indicating less influence on ethical leadership practices. Ethical behaviors such as people orientation, fairness, ethical guidance, integrity and concern for people, have positive effect on ethical leadership practices of the bank and concern for such ethical behavior, developing and encouraging applying such ethical dimensions practices are with less concern where their significances are high.

\section{Recommendations}

Based on major findings and conclusions drawn, the following recommendations are forwarded to CBE South Addis Ababa District so as to improve the ethical leadership practices of the bank. These are strategy or mechanism which should be implemented to strengthen the current ethical leadership practices from moderate level to higher level. Strategies such as training, seminars and continuous platform of ethical leaders developing for managers and its employees in regular basis must be undertaken to make the managers proactive for issues of ethical leadership.

The bank must exhaustively work in some ethical behaviors like fairness, for its practice is less likely than others and the others ethical leadership practice need to increase the current status. There is difference in ethical behaviors and ethical leadership practices in perception and gap in significance and correlation. The bank need to work in order to bridge the variation between ethical behavior and ethical leadership practices. Therefore, initiatives to reform ethical leadership practices of the bank in general as CBE and for SAAD in particular is needed.

Ethical leadership behaviors such as integrity showed high influence on ethical leadership practices of the bank, so that the bank should enhance factors those impacting ethical leadership of the bank and works for betterment in ethical behaviors not showing impact on ethical leadership practices. Among the ethical behaviors role clarification and power sharing are the ethical behaviors requiring more concern to strengthen its significance or impact on ethical leadership practices of the bank. The bank management, employees and all concerned governing bodies of the bank need to work for betterment of ethical leadership practice of the bank taking into account all ethical behaviors such as fairness, power sharing, people orientation, role clarification, concern for sustainability, ethical guidance and integrity even though some of these behaviors are highly significant and while others have less impacting ethical behaviors for the ethical leadership practices of the bank.

\section{References}

Abdurezak Mohammed, K., \& Michael W, T. (2019). Employee Performance Management System Practices and Challenges: A Case of Commercial Bank of Ethiopia and. College of Business and Economics, School of Commerce, Addis Ababa University, Ethiopia, 8.

Ahmad, I., \& Gao, Y. (2017). A Review of Ethical Leadership and Other Ethics Related Leadership Theories. 13. Al, G., \& Ronald, M. G. (2013). Virtues of Outstanding Leaders (First). John Wiley \& Sons, Inc.

Ali Award, N. H., \& Ali Khalif, S. M. (2018). The Relationship between Ethical Leadership Behavior and Organizational Identification as Perceived by Critical Care Nurses. Novelty Journals, 5. www.noveltyjournals.com

Alof, L. (2014). Is Ethical Leadership Always Beneficial? Maastricht.

Armstrong, M. (2006). Human Resource Management Practice. Kogan Page.

Asnake, Z., \& Mekonnen, Y. (2019). Unethical Leadership and Followers' Deviance: The Mediating Role of Perception of Politics and Injustice. 12. https://scholar.valpo.edu/jvbl/vol12/iss1/12

Bass, B. M., \& Riggio, R. E. (2006). Transformational Leadership. Lawrence Erlbaum Associates, Inc. 
Biruk, A. (2018, July 14). Morale Dented as CBE Employees Left out of Structural Change Benefits. https://www.thereporterethiopia.com/article/

Brown, M. E., \& Mitchell, M. S. (2010). Ethical and Unethical Leadership: Exploring New Avenues for Future Research.

Brown, M. E., \& Treviño, L. K. (2006). Ethical leadership: A review and future directions. 17.

Brown, M. E., Treviño, L. K., \& David A., H. (2005). Ethical leadership: A social learning perspective for construct development and testing. 97.

CBE Ethiopia, C. B. of. (2012). About CBE. https://www.combanketh.et

Celik, A., Akgemci, T., \& Akyazi, T. E. (2016). A comparison between the styles of transformational leaders and authentic leaders in crisis management. 6.

Copeland, M. K. (2014). The Emerging Significances of Values Based Leadership. Regent University, 8.

Day, D. V. (2014). The Oxford Handbook of Leadership and Organizations. Oxford University Press.

Draft, R. L. (2008). The Leadership Experience. Thomson South-Western.

Fowler, D. J. (2014). An Investigation of Ethical Leadership Perspectives among Ohio School District Superintendents. The Patton College of Education of Ohio University.

Hendriks, E. (2011). Ethical Leadership and Moral Behavior of Employees. Tilburg.

Ismail, I. B., \& Yaakob, B. D. (2014). Influence of Ethical Leadership towards Organizational Commitment in Schools. 4.

Johdi Salleh, M., \& Arryani Tiyunin, Z. (2014). Best Practice of Ethical Leadership among the Academic Administrators in Islamic Tertiary Education Institution: Academic Staff's Perceptions. International Journal of Humanities and Social Science Invention, 3.

Johnson, C. E. (2018). Meeting the Ethical Challenges of Leadership (Sixth). George Fox University: Sage Publications.

Joseph, C. R. (1993). Leadership for the Twenty First Century. Greenwood Publishing Group.

Kalshoven, K., Den Hartog, D. N., \& B. De Hoogh, A. H. (2011). Ethical Leader Behavior and Big Five Factors of Personality. Springer, 100. https://www.jstor.org/stable/41475845

Kalshoven, K., Den Hartog, D. N., \& De Hoogh, A. H. B. (2010). Ethical leadership at work questionnaire (ELW): Development and validation of a multidimensional measure. 22.

Kalshoven, K., \& Hartog, D. N. D. (2009). Ethical Leader Behavior and Leader Effectiveness: The Role of Prototypicality and Trust. 5.

Kar, S. (n.d.). Ethical Leadership: Best Practice for Success. www.iosrjournals.org

Katja Mihelič, K., Bogdan, L., \& Metka, T. (2010). Ethical Leadership: International Journal of Management \& Information Systems. 14.

Khalid, K., \& Bano, S. (2015). Can ethical leadership enhance individual's task initiatives? 3.

Khan, H. K., Yasir, M., Mohd Yusof, H., Bhatti, M. N., \& Umar, A. (2017). The relationship between ethical leadership and organizational citizenship behavior: Evidence from Pakistan.

Khodarahmi, R., \& Aghahoseini, T. (2014). The Relationship between Ethical Leadership and Empowerment of Employees in the Tax Affairs of Isfahan City. 4. http://dx.doi.org/10.6007/IJARBSS/v4-i6/957

Locke, E. A. (2009). Handbook of principles of organizational behavior. John Wiley \& Sons, Ltd.

Matthew R., F. (2002). Defining Leadership: A Review of Past, Present, and Future Ideas.

Melesse, M. (2017). The effect of work life balance on employee's commitment in Commercial Bank of Ethiopia. AAU.

Nancy Langton, S. P. R., s. (n.d.). Fundamentals of Organizational Behavior: Understanding the Work Place.

Northouse, P. G. (2013). Leadership Theory and Practices (Sixth). Saga publishing's.

Palanski, M. E., \& Yammarino, F. J. (2009). Integrity and Leadership: A multi-level conceptual framework. 20. https://doi.org/10.1016/j.leaqua.2009.03.008

Rahim, N., \& Ahmad-Zaluki, N. A. (2018). The extent of ethical leadership among youth: The case of a developing country. Malaysian Journal of Society and Space. https://doi.org/10.17576/geo-2018-1404-05

Rita Men, L. (2015). The role of ethical leadership in internal communication. 9.

Robbins, S. P., \& Dame, N. (2013). Organizational Behavior (15th ed.). Pearson Education, Inc.

S. Fernando, R. L. (2018). Ethical Leadership Measures for Public Service in Sri Lanka. Canadian Center of Science and Education, 11. https://doi.org/10.5539/ibr.v11n7p106

Steinmann, B., Nübold, A., \& W. Maie, G. (2016). Validation of a German Version of the Ethical Leadership at Work Questionnaire by Kalshoven. 7.

Tavakol, M., \& Dennick, R. (2011). Making Sense of Cronbach's Alpha,” International Journal of Medical Education. 2. https://doi.org/10.5116/ijme.4dfb.8dfd.

Taylor, D. H. (2010). The power of value-based leadership. www.DavisHTaylor.com

Toor, S.-R., \& Ofori, G. (2009). Ethical Leadership: Examining the Relationships with Full Range Leadership Model, Employee Outcomes, and Organizational Culture. 90 No.4. 
Vima, Z. (2018). Leadership values and values based leadership. 15.

Wolmarans, J. (2014). The Effect of Core Ethical Values on Ethical Leadership, Organizational Justice, Ethical Climate and Leader Effectiveness. Stellenbosch University.

Yardley, I., Kakabadse, A., \& Neal, D. (2012). From battle field to boardroom. Palgrave Macmilan.

Yukl, G., Mashud, R., Hassan, S., \& Prussia, G. E. (2013). An Improved Measure of Ethical Leadership. http://jlo.sagepub.com/content/20/1/38 